\title{
Self-perceived Listening Comprehension Strategies Used by Iranian EFL Students
}

\author{
Sara Nowrouzi (Corresponding Author) \\ English Language Department, Faculty of Languages and Linguistics, University of Malaya, saranoroozi@gmail.com \\ Tam Shu Sim \\ English Language Department, Faculty of Languages and Linguistics, University of Malaya \\ Gholamreza Zareian \\ Department of English Language and Literature, School of Humanities, Hakim Sabzevari University, Iran \\ Vahid Nimehchisalem \\ English Language Department, Faculty of Modern Languages and Communication, Universiti Putra Malaysia
}

Received: 12-04-2014

doi:10.7575/aiac.ijalel.v.3n.6p.35
Accepted: 17-06-2014

Published: 01-11-2014

\begin{abstract}
Numerous studies are available on L2 learners' strategy use; however, there is no study investigating the Iranian tertiary level EFL learners' listening strategy use. The present paper reports the findings of a cross-sectional study that explored a group of Iranian EFL learners' $(n=100)$ use of listening comprehension strategies. The instrument that was used for collecting the data was called the Listening Strategy Use Questionnaire (LSUQ) by Nowrouzi, Tam, Nimehchisalem, and Zareian (2014). The instrument divides listening strategies into cognitive, metacognitive, and socio-affective categories. Based on the results, on average the respondents reported low levels of self-perceived use of cognitive, metacognitive, and socio-affective strategies. The results indicate a serious need to focus more on the students' listening comprehension skills in general and their listening strategies in particular.
\end{abstract}

Keywords: EFL language teaching and learning, Listening skills, Listening strategies

\section{Introduction}

Since late 1970s, there has been a widespread research interest in the strategies that learners use for learning foreign or second languages and in variables related to effective strategy use including language proficiency and metacognitive awareness. These research projects range from studies on the use of all strategies in general to thorough exploration of certain strategies regarding particular skills or language areas (Eckerth, Schramm, \& Tschirner, 2009). The body of work to date suggests a possible relationship between strategy use and second language learning success. This interest has also given rise to a number of studies in language learner strategy instruction that provides some evidence on the possibility of helping learners to use strategies more effectively (Macaro, 2006).

\section{Classification of L2 Learners' Listening Strategies}

Listening strategies are activities or techniques which directly contribute to the comprehension of listening input and its recall (National Capital Language Resource Center, 2004). In line with general learning strategies categorized by O'malley and Chamot (1990), listening strategies can be classified into three types: cognitive (mental activities for manipulating the language to accomplish a task), metacognitive (mental activities for directing language learning), and socio-affective (activities involving interaction or affective control in language learning) (Vandergrift, 1997, 2003). Each of these categories will be discussed in the following section.

\subsection{Cognitive strategies}

Cognitive strategies in listening are classified by National Capital Language Resource Center (2004) into top-down and bottom-up processing types. Top-down processing strategies are listening for the main idea, predicting, drawing inferences, and summarizing while bottom-up processing strategies include listening for specific details, recognizing cognates, and recognizing word-order patterns. A more extensive taxonomy of cognitive strategies is suggested by Bacon (1992) who adds summarization, translation, elaboration, and transfer strategies to the above-mentioned topdown and bottom-up processing types. However, Vandergrift $(1997,2003)$ presents a comprehensive list of cognitive strategies, including inferencing, elaboration, summarization, translation, transfer, repetition, responding, grouping, note-taking, deduction/induction, and substitution.

\subsection{Metacognitive Strategies}

Bacon (1992) classifies metacognitive strategies into three types that are used before, during, and after listening. Before listening, the learners prepare for listening through manipulating the environment, focusing attention, applying an 
advance organizer, selective attention, and deciding to think in English. During listening, they try to direct their attention, monitor their listening, and express interest. And after listening, they evaluate their comprehension and try to identify what helped listening to be used in future. In a basically similar way but in different terms, Goh (2008) generally classifies these strategies into planning, monitoring, and evaluating one's listening in general. However, Vandergrift et al. (2006) consider metacognitive strategies as a part of metacognitive awareness that also includes person knowledge. In this taxonomy, metacognitive strategies are composed of four factors: planning/evaluation, directed attention, problem solving, and avoiding mental translation.

\subsection{Socio-Affective Strategies}

Bacon (1992) regards appealing for help and asking for confirmation as the social strategies and reassuring oneself as the only affective strategy in her taxonomy. However, Vandergrift $(1997,2003)$ adds cooperation to the social strategy list and lowering anxiety as well as taking emotional temperature (awareness of one's emotions while listening in order to avert negative emotions and to make the most of positive emotions) to the affective strategies.

\section{Previous Studies on Listening Comprehension Strategies}

Research in language learning strategies is originally rooted in three early studies by Rubin (1975), Stern (1975) and Naiman et al. (1978) on what good language learners do. These researchers investigated what characterizes good language learners who are more successful than others in learning a second language. They found that students' own active and creative participation in the learning through the application of individualized learning techniques causes some learners to excel.

Since late 1990s, there has been a gradually increasing revival of research interest in learning strategies showing the relationship between learning strategies and age, gender, proficiency level, cognitive styles, motivation, culture and context, task type, and the like (Fan, 2003; El-Dib, 2004; Oxford et al., 2004; Chamot, 2005). Some intervention studies have also been conducted to document the effectiveness of strategy training in developing learners' efficiency in listening, speaking, reading, writing, and vocabulary (Ozeki, 2000; Cohen, Weaver, \& Li, 1998; Oxford et al., 2004). Most of these researchers indicate the positive relationship between strategy use and language learning success. Learning strategies make learning "easier, faster, more enjoyable, more self-directed, more effective, and more transferable to new situations" (Oxford, 1990, p. 8).

Strategy related studies have sparked substantial interest among researchers in Iran since late 1990s. In line with the global research, the main focus has been on correlation between Iranian students' strategy use and gender, proficiency level, learning styles, motivation, attitude, field of study, tolerance of ambiguity, personality, and the like (Borzabadi, 2000; Ebrahimi, 2002; Khajeh, 2002; Rahimi, 2004; Yadegari, 2004). In addition, some intervention studies have been done on the effectiveness of strategy training on students' learning efficiency specially vocabulary and reading comprehension (Etemad, 1998; Alvari, 1998; Ranjbari, 2000; Farshid, 2003). However, little is known on the nature of listening strategies used by tertiary level Iranian English as a Foreign Language (EFL) students. The present paper reports the results of a study that explored the listening comprehension strategies used by a group of tertiary level EFL students in Khorasan Razavi Province, Iran.

\section{Objectives and Research Questions}

This study aims to identify the Iranian tertiary level EFL learners' listening comprehension strategies. More specifically, the study investigates the level of learners' use of the three types of listening comprehension strategies mentioned above including metacognitive, cognitive, and socio-affective strategies. To meet this objective the following research questions were addressed:

1. To what extent do Iranian tertiary level EFL learners use metacognitive listening comprehension strategies?

2. To what extent do Iranian tertiary level EFL learners use cognitive listening strategies?

3. To what extent do Iranian tertiary level EFL learners use socio-affective listening strategies?

The results will provide a useful profile of the listening strategies used by the Iranian tertiary level EFL learners'. They are expected to be of significance for educational policy makers and English language lecturers who wish to improve the learners' listening comprehension skills.

\section{Method}

A quantitative research method was employed following a cross-sectional design to answer the research questions. Data were collected using survey method. The respondents, instrument, data collection procedure, and data analysis procedure will be explained below.

\subsection{Respondents}

The respondents in this study were 100 students randomly selected from four universities in Khorasan Razavi Province, Iran after permission had been obtained from the related authorities. The respondents were aged between 19 and 23 and a majority of them (70\%) were females. They were from English Language and Literature department, Faculty of Humanities, all majoring in English.

\subsection{Instrument}

The data were collected through a questionnaire on listening strategy use (henceforth LSUQ). Nowrouzi, Tam, Nimehchisalem, and Zareian (2014) provide a detailed account of how this questionnaire was developed and validated. Briefly, this questionnaire was developed based on a detailed literature review and similar studies on listening such as those by Bacon (1992), Cohen, Oxford, and Chi (2005), Vandergrift (1997, 2003, 2007) and Vandergrift et al. (2006). It was validated through a process of item construction (and sometimes item adoption or adaptation), expert judgment, 
and field-testing. The final questionnaire had 32 items and a 5-point Likert scale (from 1 signifying 'never' and 5 meaning 'always'). The first 15 items related to cognitive strategies (e.g., Using known words in an utterance to guess the meaning of unknown words). Items 19 to 27 related to the metacognitive strategies (e.g., Listening for key words). Finally, items 28 to 32 elicited information on the respondents' socio-affective strategies (e.g., Asking others for help). The Cronbach's alpha value of internal consistency of the instrument was 0.87 in this study.

\subsection{Data Collection Procedure}

After the validation stage, a group of 100 randomly selected learners signed written consent forms. Then the questionnaire was administered to these learners to determine their self-perceived listening strategy use. Before administration of the questionnaire, the course instructor was asked to present a listening activity to the learners, "so that learners would have a specific task on which to base their responses" (Vandergrift et al, 2006, p. 441). The first author then explained about the importance of the research and the need for the learners to cooperate and respond carefully in order to make the results of the research more reliable. She then answered learners' questions about the survey. The learners were assured that all data collected would be kept anonymous. The questionnaires were distributed among the participants to be completed and all these procedures took approximately 60 minutes. Learners were asked to double check their survey responses and return the questionnaires to the first author directly. Therefore, the response rate was $100 \%$ and none of the completed questionnaires had to be discarded.

\subsection{Data Analysis Procedure}

SPSS (Version16) was used to analyze the data. The statistical methods that were used were descriptive methods such as frequency, percentage, means, and standard deviations. A five-point Likert scale is used in the questionnaire $(1=$ never, $2=$ rarely, $3=$ sometimes, $4=$ usually, and $5=$ always). Oxford's (1990) rating scheme for strategy use was used to distinguish between low, medium and high levels of strategy use so that a mean of 3.5 to 5 shows a high, 2.5 to 3.4 a moderate, and 1.0 to 2.4 a low level of problems.

\section{Results}

The results have been reported in this section following the order of the research questions which divided the strategies into three cognitive, metacognitive, and socio-affective categories.

\subsection{Cognitive Strategy Use}

Based on the analysis of the students' responses to the first 12 items in LCSQ, the level of their perceived cognitive strategy use was measured. Table 1 presents these results.

Table 1. Cognitive Strategies

\begin{tabular}{|c|c|c|c|}
\hline Item & Mean & $\mathrm{SD}$ & Level* \\
\hline 1: I put new words into a context to understand the meaning. & 1.57 & 69 & Low \\
\hline 2: I make guesses about the topic based on what has already been said. & 2.12 &. .69 & Low \\
\hline 3: I use the tone of voice to guess the meaning of what I hear. & 2.02 & 61 & Low \\
\hline 4: I use body language to guess the meaning of what I hear. & 2.00 & .54 & Low \\
\hline $\begin{array}{l}\text { 5: I use material in the answer sheet (e.g. the printed items, choices and } \\
\text { pictures) to guess the meaning of what I hear. }\end{array}$ & 1.89 & .61 & Low \\
\hline $\begin{array}{l}\text { 6: I practice sounds in the target language that are very different from sounds } \\
\text { in my own language to become comfortable with them. }\end{array}$ & 3.62 & 1.18 & High \\
\hline 7: I listen to the radio in the target language. & 3.44 & 1.13 & Moderate \\
\hline 8: I watch English programs on TV. & 3.13 & 1.08 & Moderate \\
\hline 9: While listening, I make a written summary of the main points. & 1.77 & .73 & Low \\
\hline 10: I make a mental summary of information presented in a listening task. & 1.49 & .75 & Low \\
\hline 11: I take notes of main points and keywords. & 2.53 & 1.33 & Moderate \\
\hline 12: I watch movies in the target language. & 3.70 & .99 & High \\
\hline Total average & 2.44 & .86 & Low \\
\hline
\end{tabular}

*Mean values 1-2.4 (low), 2.5-3.4 (moderate); and 3.5-5 (high) levels of listening problems

Based on the results, the learners have reported low levels of all cognitive strategies, excluding rehearsal strategies, which include 'listening to the radio in the target language', 'watching English programs on TV', 'watching movies in the target language', and 'practicing new sounds'. 
6.2 Metacognitive Strategy Use

Table 2 presents the means, standard deviations and levels of metacognitive strategy use by the Iranian tertiary level EFL students.

Table 2. Metacognitive Strategies

\begin{tabular}{|c|c|c|c|}
\hline Item & Mean & SD & Level* \\
\hline 13: I have a plan in my mind before listening & 2.15 & .95 & Low \\
\hline $\begin{array}{l}\text { 14: I prepare for talks and performances I will hear in the target language by } \\
\text { reading some background materials beforehand. }\end{array}$ & 2.36 & 1.20 & Low \\
\hline $\begin{array}{l}\text { 15: I decide to focus on the topic and ignore the distracters such as people and } \\
\text { things around me }\end{array}$ & 2.01 & .91 & Low \\
\hline 16: I try to listen for specific details to see whether I can understand them. & 3.51 & .86 & High \\
\hline 17: I listen for key words. & 2.03 & .95 & Low \\
\hline 18: I try to understand what I hear without translating it word-for-word. & 2.83 & .93 & Moderate \\
\hline 19: I use my experience and knowledge to help me understand. & 2.60 & 1.37 & Moderate \\
\hline 20: I try to keep up with the speed. & 2.33 & .89 & Low \\
\hline $\begin{array}{l}\text { 21: I try to compare the developing interpretation with my knowledge of the } \\
\text { topic }\end{array}$ & 2.20 & 1.41 & Low \\
\hline $\begin{array}{l}\text { 22: I Quickly adjust interpretation during listening if I realize that it is not } \\
\text { correct. }\end{array}$ & 2.04 & 1.14 & Low \\
\hline $\begin{array}{l}\text { 23: I Think back to everything heard to verify the meaningfulness of guessed } \\
\text { words. }\end{array}$ & 2.34 & .81 & Low \\
\hline $\begin{array}{l}\text { 24: As I listen, I sometimes ask myself if I am satisfied with my } \\
\text { comprehension. }\end{array}$ & 2.37 & .85 & Low \\
\hline $\begin{array}{l}\text { 25: After listening, I think back to how I listened and about what I might do } \\
\text { differently next time. }\end{array}$ & 1.88 & .79 & Low \\
\hline $\begin{array}{l}\text { 26: After listening, I think back to the quality of my strategy use (for example } \\
\text { planning, inferencing) and about how I can do better next time. }\end{array}$ & 2.28 & 1.10 & Low \\
\hline $\begin{array}{l}\text { 27: I prepare a list of my problems and try to solve them before my next } \\
\text { listening }\end{array}$ & 2.47 & 1.44 & Low \\
\hline Total average & 2.36 & 1.04 & Low \\
\hline
\end{tabular}

*Mean values 1-2.4 (low), 2.5-3.4 (moderate); and 3.5-5 (high) levels of listening problems

As displayed in this table, the learners reported low levels of self-perceived use, in almost all metacognitive strategies excluding 'listening for specific details, using one's experience and knowledge to help him understand, and 'avoiding word-for-word translation'.

\subsection{Socio-Affective Strategy Use}

The results of items related to Socio-Affective strategies (items 28-32) are displayed in Table 3.

Table 3. Socio-Affective Strategy Use

\begin{tabular}{lccc}
\hline \multicolumn{1}{c}{ Item } & Mean & SD & Level* \\
\hline $\begin{array}{l}\text { 28: I ask others for feedback on how to solve my listening problems. } \\
\text { 29: I attend out-of-class events like conferences where the new language is } \\
\text { spoken. }\end{array}$ & 1.90 & .51 & Low \\
30: I imitate the way native speakers talk. & & 1.02 & Moderate \\
31: I encourage myself to listen more even when I am afraid of problems in \\
$\quad \begin{array}{l}\text { understanding. } \\
\text { 32: I give myself a reward or treat when I improve in listening. }\end{array}$ & 1.97 & .92 & Moderate \\
\hline Total average & 1.91 & .70 & Low \\
\hline
\end{tabular}

*Mean values 1-2.4 (low), 2.5-3.4 (moderate); and 3.5-5 (high) levels of listening problems 
With regard to the individual socio-affective strategy use, learners mostly reported low levels of use of cooperation, self-encouragement, and self-rewarding except in two social strategies ('Attending out-of-class events like conferences where the new language is spoken' and 'Imitating the way native speakers talk'). Table 4 summarizes the results for all three categories.

Table 4. A summary of EFL learners' levels of listening strategy use

\begin{tabular}{lcc}
\hline Strategy & Mean & Level* \\
\hline Cognitive & 2.44 & Low \\
Metacognitive & 2.36 & Low \\
Socio-affective & 2.20 & Low
\end{tabular}

* Mean values 1-2.4 (low), 2.5-3.4 (moderate); and 3.5-5 (high) levels of

listening problems

The questionnaire findings on strategies, as summarized in Table 4, show that the lowest level for the socio-affective strategies $(M=2.20)$ and the highest mean $(M=2.44)$ for cognitive strategies (Table 4).

\section{Discussion}

The results of the listening strategy use survey generally showed a low frequency of metacognitive, cognitive and socio-affective strategies. Overall, 23 out of 32 strategies were reportedly used with a low frequency.

The socio-affective strategies obtained the lowest level of use among the three listening comprehension strategies. This showed that Iranian learners have limited social opportunities for practice. Such results are due to the EFL context in Iran where the interaction is limited to the classroom situations. A large amount of listening input at universities is based on teacher talk (Bigdeloo, 2001; Bustamante, 1991; Siahcheshm, 1994; Shahsavan, 2004) and students are not often exposed to authentic listening situations outside class. An emphasis should be given to teaching the affective strategies regarding the importance in avoiding the affective problems such as low self-confidence, anxiety, low motivation, embarrassment and nervousness that hinder listeners from effective performance (Cross, 2011; Liu, 2002; Tafaghodtari, 2009; Tafaghodtari \& Vandergrift, 2008; Vandergrift, 2011).

As to the cognitive strategies, the students reported using only two ('Seeing movies in the target language' and 'Practicing target language sounds') out of the 12 cognitive strategies. The emphasis on specific sounds reflects the role of pedagogy on strategy use (Eastman, 1991). Iranian teachers focus on the presentation and practice of sounds in isolation (Ahmadi, 2007). Using movies as the only source for students' practice shows that Iranian learners' have limited listening practice and so insufficient exposure to English. This can be attributed to the fact that, they did not use other practice types because of the negative washback effect of pedagogical objectives and activities whereby the learners feel no need to improve their listening. Instead, they use most of their time practicing reading, grammar, and vocabulary with little time left for listening. This necessitates the learning strategy instruction to make them familiar with the importance and use of such strategies.

The results related to insufficient exposure to English also reported by Liu (2002, p. 146) who considers "limited exposure to varieties of spoken English" as a factor influencing learners' overall listening difficulties.

The learners reported high levels of using metacognitive strategies of, 'listening for specific details' as well as frequent use of translation. This can be related to pedagogical factors (Eastman, 1991, p.179). In spite many innovative methods such as Asher's Total Physical Response, Krashen's Natural Approach, Curran's Community Language Learning, Lozanov's Suggestopedia, and Gattegno's Silent Way have been proposed since the last 30 years (Feyten, 1991), many teachers in Iran still stick traditional methods of Grammar Translation in classes and are neither familiar with the innovative methods nor proficient enough in language (Akbari, 2005; Hassani, 2003). The result related to high level of 'listening for specific details' is accordance with Osada's (2001) study which showed that low proficiency students relied merely on bottom-up strategies of using the textual information and failed in activating their top-down strategies to understand the listening material. Therefore, it can be said that proficiency is also an important factor in successful use of some strategies.

\section{Conclusion}

Based on the result of the present study, the least frequently used strategies are socio-affective strategies followed by metacognitive and cognitive ones. Moreover, the results showed that Iranian learners prefer bottom-up strategies and use them more than the top-down ones. It can be concluded that in L2 listening courses an emphasis should be given to teaching the socio-affective strategies especially the affective ones regarding the importance in avoiding the affective problems such as low self-confidence, anxiety, low motivation, embarrassment and nervousness that hinder listeners from effective performance (Cross, 2011; Liu, 2002; Tafaghodtari, 2009; Tafaghodtari \& Vandergrift, 2008; Vandergrift, 2011).

The importance of appropriate methods in teaching listening has been the focus of many studies in listening to help learners overcome their problems and have effective listening experiences. For instance, Vandergrift and Goh (2009) suggest the interactive model of teaching listening in which both bottom-up and top-down processing skills are taught. 
Accordingly, many books and instructional materials (Brown, 2001; Richards, 1988; Rost, 2002; Ur, 1984) have provided guidelines and exercises for teachers to improve both bottom-up and top-down processing abilities.

In Iran, most university students are not able to understand authentic listening materials as they are expected to (Shahsavan, 2004) and many of them are dissatisfied with the instruction they receive because of the ineffective methodology in meeting their needs in real life situations (Zoroufchian, 2005). When dealing with a communicative task like listening, tertiary level language learners do not know what works best for them in fulfilling the task and only resort to traditional ineffective strategy of looking up every word from the dictionary (Farshid, 2003). It shows that they need training in using listening strategies more frequently that according to Vandergrift (1997a) will help them succeed in communication.

The results clearly show the students' serious need to learn what listening comprehension strategies are and how they can be used effectively in EFL listening comprehension activities. It should be noted that the respondents of this study were all majoring in English language teaching or English literature, who are expected to have better levels of English language proficiency compared with students from other majors. Further research is recommended on university level students majoring in other disciplines. Additionally, intervention studies on Iranian EFL learners' listening strategy use can show whether strategies can affect students' listening proficiency.

\section{References}

Alvari, A. (1998). Learners' strategies in vocabulary learning: A case study of Iranian EFL university students. MA Thesis. Shiraz University, Iran.

Asgary, H. A. (2001). The relationship between the level of listening and the choice of listening strategies by Iranian EFL undergraduate students. MA Thesis. University of Science and Technology, Iran.

Bacon, S. M. (1992). The relationship between gender, comprehension, processing strategies, and cognitive and affective response in foreign language listening. Modern Language Journal, 76(2), 160-177.

Borzabadi, F. D. (2000). The relationship between language learning strategies and fields of study, sex, language proficiency, and learning styles. $\mathrm{PhD}$ Thesis. Allameh Tabatabie University, Iran.

Chamot, A. U. (2005). Language learning strategy instruction: Current issues and research. Annual Review of Applied Linguistics 25, 112-130.

Cohen, A.D., Weaver, S. J., \& Li, T. Y. (1998). The impact of strategies-based instruction on speaking a foreign language. In A. D. Cohen (Ed), Strategies in learning and using a second language (pp. 107-156). London: Longman.

Ebrahimi, A. (2002). A comparative study of language learning strategies employed by bilinguals and monolinguals with reference to attitudes and motivation. MA Thesis. Teacher Training University, Iran.

Eckerth, J., Schramm, K., \& Tschirner, E. (2009). Review of recent research (2002-2008) on applied linguistics and language teaching with specific reference to L2 German (part 1), Language Teaching, 42(1), 41-66.

El-Dib, M.A.B. (2004). Language learning strategies in Kuwait: Links to gender, language level, and culture in a hybrid context. Foreign Language Annals, 37(1), 85-95.

Etemad, B. (1998). The role of vocabulary learning strategies on vocabulary retention and on language proficiency in Iranian EFL students. MA Thesis. Teacher Training University, Iran.

Fan, M. Y. (2003). Frequency of use, perceived usefulness, and actual usefulness of second language vocabulary strategies: A study of Hong Kong learners. Modern Language Journal, 87(2), 222-241.

Farshid, M. (2003). The effects of separate and integrated presentation of reading strategies on the reading comprehension ability of the Iranian students. MA Thesis. Allameh Tabatabaie University, Iran.

Goh, C. C. M. (2008). Metacognitive instruction for second language listening development: Theory, practice and research implications RELC Journal, 39(2), 188-213.

Hadji Vosuq, S. A. (2000). The relationship between the form of material (dialog vs. monolog) and note-taking, and listening comprehension. MA Thesis. Tarbiat Modares University, Iran.

Khajeh, A. (2002). Relationship between tolerance of ambiguity, gender, level of proficiency, and use of second language learning strategies. MA Thesis. Tarbiat Modares University, Iran.

Liu, N. F. (2002). Processing problems in L2 listening comprehension of university students in Hong Kong. (Doctoral dissertation). Retrieved on April 5, 2010 from ProQuest Dissertations \& Theses database. (UMI No. 3074191)

Macaro, E. (2006). Strategies for language learning and for language use: Revising the theoretical framework. Modern Language Journal, 90(3), 320-337.

Naiman, N., Fröhlich, M. Stern, H. H. \& Todesco. A. (1978). The good language learner. Toronto: Ontario Institute for Studies in Education.

National Capital Language Resource Center (NCLRC). (2004). The essentials of language teaching: Strategies for developing listening skills. Washington, DC: National Capital Language Resource Center. Retrieved on April 5, 2007 from http://www.nclrc.org. 
Nowrouzi, S., Tam, S. S., Nimehchisalem, V., and Zareian, G. (2014). Developing an instrument for Iranian EFL learners' listening comprehension problems and listening strategies. Advances in Language and Literacy Studies 5(3).

O’Malley, J. M. \& Chamot, A. U. (1990). Learning strategies in second language acquisition. Cambridge: Cambridge University Press.

Oxford, R. L. (1990). Language learning strategies: What every teacher should know. New York: Newbury House.

Oxford, R., Cho, Y., Leung, S. \& Kim, H-J. (2004). Effect of the presence and difficulty of task on strategy use: An exploratory study. International Review of Applied Linguistics, 42(1), 1-47.

Ozeki, N. (2000). Listening strategy instruction for female EFL college students in Japan. PhD Thesis. Indiana University of Pennsylvania.

Rahimi, M. (2004). An investigation into factors affecting the Iranian EFL students' perceived use of language learning strategies. PhD Thesis. Shiraz University, Iran.

Ranjbari, R. (2000). The impact of metacognitive vocabulary learning strategy instruction on lexical knowledge of Iranian EFL students. MA Thesis. Iran University of Science and Technology.

Rubin, J. (1975). What the 'Good Language Learner' can teach us. TESOL Quarterly, 9(1), 41-51.

Sedaghat. M. (2001). The effects of attitude, motivation (instrumental and integrative) and proficiency level on the use of listening comprehension strategies by Iranian female EFL students. MA Thesis. Shiraz University, Iran.

Stern, H. H. (1975). What can we learn from the good language learner? Canadian Modern Language Review, 31(4), 304-318.

Vandergrift, L. (1997). The comprehension strategies of second language (French) listeners: A descriptive study. Foreign Language Annals, 30(3), 387-409.

Vandergrift, L. (2003). Orchestrating strategy use: Toward a model of the skilled second language listener. Language Learning, 53(3), 463-496.

Vandergrift, L., Goh, C. C. M. Mareschal, C. \& Tafaghodtari, M. H. (2006). The metacognitive awareness listening questionnaire: Development and validation. 56(3), 431-462.

Yadegari, S. (2004). The relationship between personality types and language learning strategies deployed by EFL distance learners. MA Thesis. Tarbiat Modares University, Iran. 